\title{
Roles of TGF $\beta$ and FGF Signals in the Lens: Tropomyosin Regulation for Posterior Capsule Opacity
}

\author{
Eri Kubo ${ }^{1, *(D)}$, Teppei Shibata ${ }^{1}$, Dhirendra P. Singh ${ }^{2}$ and Hiroshi Sasaki ${ }^{1}$ \\ 1 Department of Ophthalmology, Kanazawa Medical University, Ishikawa 9200293, Japan; \\ prefse74@yahoo.co.jp (T.S.); mogu@kanazawa-med.ac.jp (H.S.) \\ 2 Department of Ophthalmology and Visual Science, University of Nebraska Medical Center, \\ Omaha, NE 68198, USA; dpsingh@unmc.edu \\ * Correspondence: kuboe@kanazawa-med.ac.jp; Tel.: +81-76-286-2211
}

Received: 30 August 2018; Accepted: 4 October 2018; Published: 9 October 2018 updates

\begin{abstract}
Transforming growth factor (TGF) $\beta$ and fibroblast growth factor (FGF) 2 are related to the development of posterior capsule opacification (PCO) after lens extraction surgery and other processes of epithelial-mesenchymal transition (EMT). Oxidative stress seems to activate TGF $\beta 1$ largely through reactive oxygen species (ROS) production, which in turn alters the transcription of several survival genes, including lens epithelium-cell derived growth factor (LEDGF). Higher ROS levels attenuate LEDGF function, leading to down-regulation of peroxiredoxin 6 ( $\operatorname{Prd} \mathrm{x} 6)$. TGF $\beta$ is regulated by ROS in Prdx6 knock-out lens epithelial cells (LECs) and induces the up-regulation of tropomyosins (Tpms) 1/2, and EMT of LECs. Mouse and rat PCO are accompanied by elevated expression of Tpm2. Further, the expression of Tpm $1 / 2$ is induced by TGF $\beta 2$ in LECs. Importantly, we previously showed that TGF $\beta 2$ and FGF2 play regulatory roles in LECs in a contrasting manner. An injury-induced EMT of a mouse lens as a PCO model was attenuated in the absence of Tpm2. In this review, we present findings regarding the roles of TGF $\beta$ and FGF2 in the differential regulation of EMT in the lens. Tpms may be associated with TGF $\beta 2$ - and FGF2-related EMT and PCO development.
\end{abstract}

Keywords: TGF $\beta$; tropomyosin; epithelial-mesenchymal transition; reactive oxygen species; FGF; peroxiredoxin 6; lens epithelium-cell derived growth factor

\section{Introduction}

The ocular lens is a transparent organ that changes its shape to adjust the focal distance of the eye in order to focus on objects. The crystalline lens consists of non-dividing central epithelial cells, dividing epithelial cells in the germinative zone, and terminally differentiated fiber cells in the bow region. Lens epithelial cells (LECs) maintain lens homeostasis and are not shed from the lens [1]. Damage to LECs is mediated by the abnormal growth of fiber cells, imbalances in the lens transport system, and the erroneous processing of biological molecules. There is compelling evidence that the progression of cataracts is associated with aging, and that oxidative stress is the major contributor to this process. Age-related cataracts are the primary cause of blindness in the world [2]. Age-related cataracts are a heterogeneous disorder that are related to multiple environmental and lifestyle risk factors that are modified by age, sex, exposure to solar ultraviolet (UV) radiation other types of radiation, oxidative stress, and cytokines [3-5]. Recently, growth factors have been analyzed to determine their roles in age-associated disorders including age-related cataracts. It has been reported that transforming growth factor (TGF) $\beta$ is secreted in the aqueous and vitreous humors [6-10], and TGF $\beta$ has been shown to induce cataractogenesis [11]. In addition, anterior subcapsular cataracts 
have been observed in lens-specific transgenic mice expressing TGF $\beta 1$ [12]. These changes are also found in human cataracts. TGF $\beta$ isoforms have been detected in mouse, rat, and human LECs (MLECs, RLECs, and HLECs, respectively) [13]. TGF $\beta 1$ and TGF $\beta 2$ mRNA are expressed primary in cultured HLECs [14]. Other cellular abnormalities, including the elevated expression of extracellular matrix proteins (ECM), have been attributed to reactive oxygen species (ROS)-related cell signaling [15]. Oxidative stress induces several functions, including cellular transformation and EMT. It is known that ROS mediates the expression and activation of TGF $\beta$. ROS down-regulates the survival pathway(s) in LECs, attenuates gene transcription, and overstimulates TGF $\beta 1$-mediated signaling [16,17]. The TGF $\beta 1$-mediated signaling pathway leads to the up-regulation of gene expression, including the genes for the $\alpha$ smooth muscle actin ( $\alpha S M A)$ and TGF- $\beta$-induced (Big-h3) protein. Over-stimulation of these TGF- $\beta$-induced genes has been related to cataractogenesis, posterior capsular opacification (PCO), and myofibroblast-related disorders $[5,9,17]$.

PCO is a common, significant complication following cataract surgery. At present, surgical intervention is the only cure [18]; however, after cataract surgery, the growth of aberrant LECs across the lens capsule often leads to migration, fibrosis and collagen deposition. This results in secondary visual loss known as PCO, which is sometimes referred to as a "secondary cataract" or "after cataract" [19] (Figures 1 and 2A). Capsular phimosis is also caused by excessive anterior capsular fibrosis. Epithelial-mesenchymal transition (EMT) is a major cause of the progression of several eye diseases, including PCO, cataracts with anterior subcapsular fibrosis (ASF), also known as anterior subcapsular cataracts (Figure $2 \mathrm{~B}$ ), pterygium, and glaucoma, and is part of the wound-healing process post-ocular surgery $[18,20-27]$. Aberrant TGF $\beta$ signaling plays a major role in the EMT of cells and tissues akin to its role in the development of human ASF [4,28-30] and PCO [12,18,30-32]. TGF $\beta$ promotes tissue fibrosis, transdifferentiation, myofibroblast formation, EMT, fibrosis, cell proliferation, and apoptosis [33,34], by up-regulating genes such as $\alpha \mathrm{SMA}$ and tropomyosins (Tpms), which are implicated in a variety of pathogenic processes, including cataractogenesis $[35,36]$. This molecular event may be a prime cause of ASF [4,28,30] and PCO [11,12,29-31]. ASF results from abnormal proliferation and myofibroblastic changes in LECs to form white plaques that obscure vision [37]. ASF can be caused by ocular trauma and inflammatory diseases including post-intraocular surgery, atopic dermatitis and uveitis [38].

\section{Posterior Capsular Opacification(PCO)}

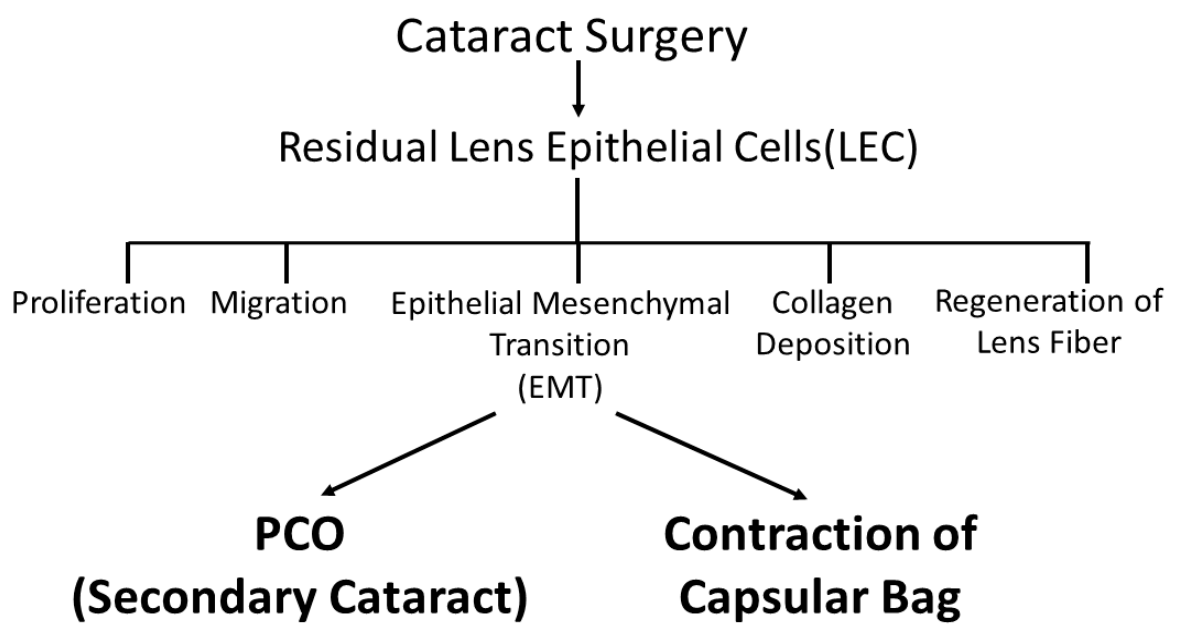

Figure 1. Changes in LECs observed in PCO. After cataract surgery, residual LECs induce cell proliferation, migration, EMT, collagen deposition and regeneration of lens fibers causing PCO, or so-called secondary cataracts. 


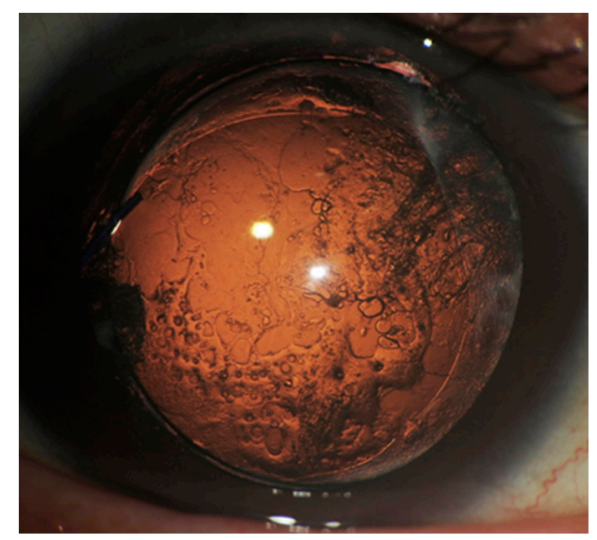

(A)

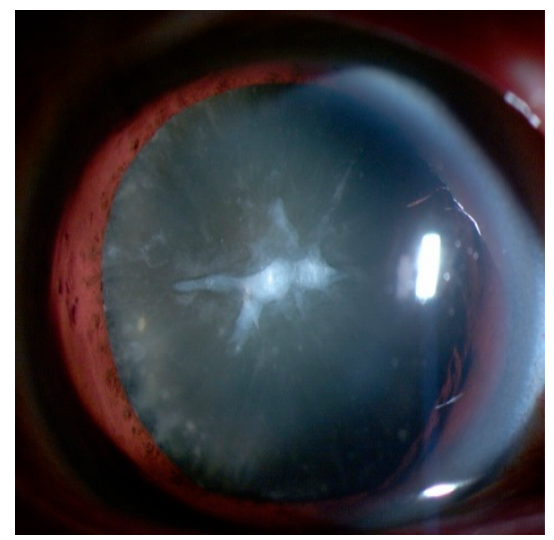

(B)

Figure 2. PCO and cataracts with Anterior subcapsular fibrosis (ASF). (A) Slit-lamp retroillumination photos of PCO development. PCO is the most common complication of cataract surgery. It is caused by the migration of residual LECs from the equatorial region of the lens capsule. (B) A slit-lamp image of a cataract with ASF. Cataracts with ASF are usually seen at the anterior pole of the lens. Fibroblastic LECs are observed in this portion.

Previous studies have suggested that fibroblast growth factor (FGF) also contributes to PCO development $[39,40]$. The concentration of FGF is higher in the vitreous chamber than the anterior chamber [41]. FGF also initiates the differentiation of LECs into fiber cells in vivo [41]. In in vitro experiments using lens epithelial explants, FGF has been shown to induce lens fiber cell elongation and differentiation [42]. FGF also induces many other cellular changes, such as cell elongation, the loss of organelles, and denucleation in the bow region of lens fibers [43-46]. In transgenic mice that over-express FGFs and FGF receptors, the normal development and growth of the lens are also impaired [47-49], indicating that FGF plays an important role in lens development and differentiation [50]. FGF2 is expressed in HLECs [51] and is involved in regulating cell proliferation and migration during lens development [52]. This molecule induces dose-dependent cell proliferation, lens fiber differentiation, and formation of collagen in LECs [44,45,50,53]. FGF2 also reduces the contraction of LEC-containing collagen gel in vitro and decreases the expression of $\alpha$ SMA in LECs [36], indicating that FGF2 reduces fibroblast function and has an effect opposite to that of TGF $\beta$ in the wound healing process. Despite the many studies on the roles of TGF $\beta$ in the lens, the mechanism underlying the synergistic action of TGF $\beta$ and FGF2 in EMT remains unclear. Moreover, the role of these molecules in gene expression, including the expression of cytoskeleton proteins such as $\alpha \mathrm{SMA}$ and Tpms during PCO development, has not been elucidated.

\section{Activation of TGF $\beta$ Is Associated with ROS, and TGF $\beta$ Generates ROS via the Down-Regulation of Peroxiredoxin 6 (Prdx6)}

Several mechanisms for TGF $\beta$ activation have been reported [54,55], including proteases, trauma, integrin, and ROS [56]. In addition, TGF $\beta 1$ has been shown to increase ROS generation through the down-regulation of antioxidant-related genes such as catalase, $\mathrm{Mn}$-superoxide dismutase and lens epithelium-derived growth factor (LEDGF) $[17,57]$. Cloned LEDGF is a survival factor and transcriptional activator [58]. LEDGF has been shown to activate cell proliferation at low concentrations. Cells expressing higher concentrations of LEDGF exhibit enhanced survival against many types of stresses [59-62]. In particular, stresses such as thermal and oxidative stress increase the expression of LEDGF mRNA and proteins [63]. Our previous study revealed that TGF $\beta 1$ treatment markedly decreased LEDGF, heat shock protein (Hsp) 27 , and $\alpha B$-crystallin promoter activities [58]. TGF $\beta 1$ induces the down-regulation of LEDGF expression and reduces the DNA binding affinity in HLECs that exhibit fibroblastic changes and apoptosis [60]. TGF $\beta 1$ suppressed the function of LEDGF by reducing its transcription and inhibiting its DNA binding [58]. Previous studies have reported that TGF $\beta$ plays a 
regulatory role in the transcription of genes containing TGF $\beta$ inhibitory elements (TIE) $[64,65]$. Our experiments established that TIE is present in the LEDGF promoter [58]. The interruption of a TIE element, nnnnTTGGnnn, found at positions -444 to -433 in the LEDGF promoter, suppressed the TGF- $\beta 1$-induced inhibition of $L E D G F$ expression [58]. Thus, the repression of $L E D G F$ may be a critical event in TGF- $\beta 1$-induced changes [58].

LEDGF activates a heat shock element (HSE; nGAAn) and a stress-related element (STRE; T/AGGGGA/T) in stress-related genes such as Hsp25, Hsp 27, Hsp90, $\alpha$ B-crystallin, and Prdx6 [63,66,67]. The over-expression of $L E D G F$ in cells induces the up-regulation of the Prdx6 protein and mRNA, and increases cell survival under oxidative and heat stress conditions [63]. Higher ROS insults attenuate the function of LEDGF in cells and subsequently lead to the decreased production of Prdx6 [63]. Six members of the Prdx family have been identified to date. Prdxs use redox-active cysteine (Cys or C) to reduce peroxides [68]. Prdx6 protects cells from environmental stresses. Notably, our report revealed the presence of all six known Prdxs in the lens; however, Prdx6 was expressed at a higher level than the others [69]. This finding indicates that the expression levels and functions of Prdxs may be tissue-specific. Moreover, several lines of evidence now demonstrate that Prdx6 is important in maintaining cellular homeostasis by controlling ROS and modulating gene regulation. In addition, Prdx6 plays an important role in cellular signaling by reducing ROS and thereby regulating gene expression [17,63,69-71].

We have shown that Prdx6-deficient $\left(\mathrm{Prdx6}^{-/-}\right)$MLECs are more vulnerable to UV-triggered cell death, and these cells display abnormal protein profiles [72]. We found that ROS levels are elevated in $P r d x 6^{-/-}$cells as well as in aged LECs [17]. Furthermore, levels of activated TGF $\beta 1$ are increased in $\operatorname{Prdx} 6^{-/-}$LECs. The addition of Prdx6 abolished the increase of activated TGF $\beta 1$, indicating that the ROS-induced activation of TGF $\beta 1$ is the major cause of EMT-like morphological changes in $P r d x 6^{-/-}$LECs [17]. In our previous studies, the expression of Prdx6 was reduced and the expression of TGF $\beta 1$ and $a S M A$ was markedly up-regulated in cataractous lenses from Shumiya cataract rats [73]. In addition, intraconjunctival injection of Prdx6 recombinant protein in the eyes of Shumiya cataract rats delayed the progression of lens opacity [73]. Bioactive TGF $\beta 1$ is also known to be present in the aqueous humor and vitreous body in humans and other species [74,75]. ROS promote the expression and activation of TGF $\beta$, which suppresses the survival pathway(s) in LECs by negatively regulating the transcription of genes such as LEDGF [17]. ROS-TGF $\beta$ signaling induces phenotypic changes in LECs and up-regulation of $a S M A$, which are similar to the effects observed in human ASF and PCO. Several previous reports also demonstrated that the activation of TGF $\beta 1$ is enhanced by ROS elevation [17,56,76-78]. ROS-driven abnormal signaling overstimulates TGF $\beta 1$-mediated signaling $[16,17,79]$. This leads to over-modulation of the expression of certain genes, such as $L E D G F, \operatorname{Prdx} 6, \alpha S M A$, Tpm, and $\beta i g-h 3$, changes in which have been implicated in the induction of cataracts, ASF and PCO as well as other EMT-related disorders $[5,9,17,80]$.

\section{Tpm and Various ECM-Related Genes are Highly Up-Regulated in Prdx6 Depletion in LECs}

In $\operatorname{Pr} d x 6^{-/-}$LECs, phenotypic changes such as the development of EMT-like morphology have been associated with the formation of lentoid bodies, a characteristic of the terminal cell differentiation of LECs [72]. To identify the proteins involved in the responses to Prdx6 depletion in MLECs, we used a proteomic differential display method, fluorescence-based difference gel electrophoresis (DIGE), coupled with matrix-assisted laser desorption/ionization time-of-flight (MALDI-TOF) mass spectrometry (MS) [72]. Comparative proteomic analysis revealed the elevated expression of cytoskeleton proteins such as Tpm1, Tpm2, Vimentin, and TGF $\beta 1$ [72]. Protein blot and real-time PCR validated marked increases in Tpm1 and Tpm2 expression in these cells. The expression of Tpm 2 mRNA was extremely low in the LECs and lenses; however, the Tpm 2 mRNA and proteins in $\operatorname{Prd} x 6^{-/-}$MLECs were highly up-regulated compared to those in wild-type MLECs [80]. We therefore hypothesized that, because Tpms have been shown to play a role in the assembly of actin filaments and the control of cell motility via the stabilization of actin filaments, aberrant expression of Tpm2 
may be related to phenotypic changes in $\operatorname{Prdx} 6^{-/-}$MLECs [80]. The actin cytoskeleton plays a significant role in the regulation of cells linked to PCO. Dysregulation of Tpm isoforms is expected to be a major indicator of EMT-like cellular changes and PCO [81,82]. The human Tpm genes were designated as TPM1 through TPM4 (Tpm1 through Tpm4 for mouse and rat Tpm) [83]. The various Tpm isoforms under each gene were generated via alternative exon splicing [83,84]. The levels of Tpm isoforms in the cells altered each of the Tpm functions [82,85-87]. Increased expression of Tpm isoforms, such as the Tpm1 and Tpm2 genes in MLECs, indicated that these isoforms play a role in

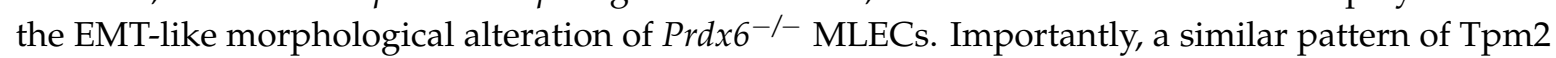
protein expression after TGF $\beta 1$ or $\mathrm{H}_{2} \mathrm{O}_{2}$ treatment was found in wild-type MLECs [35,72]. Further, the addition of exogenous Prdx6 into $\mathrm{Prdx} 6^{-/}$LECs attenuated the up-regulation of Tpm2 expression. Thus, the phenotypic alterations displayed in $\operatorname{Prdx} 6^{-/-}$MLECs may be due to the aberrant expression of the Tpm 1 and Tpm 2 genes derived from ROS-induced activation of TGF $\beta$. It has been reported that TGF $\beta$ specifically up-regulates the expression of the Tpm 1 and Tpm 2 genes, which encode low-molecular-mass Tpms [86,88]. Thus, Prdx6 may attenuate adverse ROS -TGF $\beta$ signaling, thereby reducing oxidative stress in LECs, and ultimately resulting in the maintenance of cellular homeostasis.

\section{Elevated Tpm Expression Is Associated with EMT of LECs in PCO and Human Cataracts with ASF}

We assessed the expression of isoforms from the Tpm 1 and Tpm 2 genes in a mouse and a rat model of PCO in vivo [80,89], and in LECs obtained from human subjects of various ages with cataracts [80]. Extracapsular lens extraction (ECLE) surgery was performed in the eyes of mice and rats to induce PCO. Under normal physiological conditions, the expression of Tpm1 and Tpm2 in LECs was minimal in mice and rats in vivo [80]. However, we found that the expression of Tpm1 and Tpm2 markedly increased during the development of EMT-like fibroblastic changes in LECs obtained from mice and rats with PCO, and demonstrated that the selective elevation of Tpm1 and Tpm2 in mouse and rat LECs compared to controls was correlated with EMT in the remaining LECs after ECLE $[80,89]$. The expression of $\alpha$ SMA, a marker of the differentiation and EMT of LECs, was elevated and co-localized with Tpm1 and Tpm2 in the rat with PCO [80], suggesting that the expression of Tpm1 and Tpm 2 may be associated with the progression of EMT-like changes observed in PCO. Activation of TGF $\beta$ may be induced by inflammation, mechanical stress and ROS during intraocular surgery, and would in turn induce the wound healing process and EMT by up-regulating the Tpm1 and Tpm2 genes, finally leading to PCO [80]. Moreover, we have reported that the expression of Tpm1 and Tpm2 was induced/elevated in the HLECs of human cataracts with ASF, or so-called anterior subcapsular cataracts, and in human PCO tissues surgically removed from patients affected by non-traumatic dislocated intraocular lens (IOL) [80]. Previous analysis of capsular bags from human donor eyes that received cataract surgery with IOL revealed a high level of endogenous active TGF $\beta 2$, matrix wrinkling of the lens capsule, and increased expression of $\alpha \mathrm{SMA}$ and fibronectin [13]. The induction of Tpm isoforms and stress fibers in mouse and rat PCO and LECs has been suggested to play a major role in the TGF $\beta$ regulation of myofibroblast formation and wrinkling of the lens capsule, and may be necessary for the TGF $\beta$-mediated formation of stress fibers $[80,86]$. It has been reported that Tpm 1 and Tpm 2 are responsible for the assembly of stress fibers and are targeted by TGF $\beta[86,88]$. Tpms have been shown to play a significant role in stress fiber formation by stabilizing actin filaments $[35,90]$. TGF $\beta$ specifically induces the expression of Tpm 1 and Tpm2, but is not involved in the regulation of either Tpm3 or Tpm4 $[86,88]$. Tpm knock-down by the transfection of siRNA against Tpm1 and Tpm 2 completely blocked TGF $\beta$-induced stress fiber formation in cultured mouse epithelial NMuMG and human cervical carcinoma SiHa cells, whereas the over-expression of Tm1.6 and Tm1.7 isoforms, derived from the Tpm 1 gene, induced stress fibers even without addition of TGF $\beta$ or other cytokines in human breast cancer MDA-MB-231 cells [86]. EMTs of LECs have been observed in ASF and PCO $[19,91,92]$; these changes may be affected by the TGF $\beta$-induced induction of Tpm1 and Tpm2. 
Regardless of the pathophysiological importance of Tpm isoforms, we suggest that the distinct pattern of Tpm expression may function as a clinical marker of LEC differentiation, PCO or ASF.

\section{TGF $\beta$ and FGF2 Regulate the EMT of LECs and the Expression of Tpms}

In an in vitro study using cultured MLECs and HLECs, we showed that Tpm1 and Tpm2 are involved in regulating and stabilizing actin microfilaments (F-actin) in MLECs [35]. TGF $\beta$ induces the epithelial-to-myofibroblastic transition (EMyoT) in the LECs, which is observed in the up-regulation of Tpm and $\alpha \mathrm{SMA}$, and in the formation of F-actin. Importantly, Tpms may induce the formation of stress fibers undergoing EMyoT. However, we have shown that FGF2 suppresses the TGF $\beta 2$-induced expression of Tpm1, Tpm 2 and $\alpha \mathrm{SMA}$, resulting in the recession of stress fiber formation and thereby the activation of myofibroblastic LECs, which promote cell migration [35] (Figure 3). Stress fiber formation and up-regulation of $\alpha$ SMA induced by TGF $\beta 2$ could be reversed by transfection of siRNA against the Tpm1 and Tpm2 genes [35], suggesting that Tpms may be necessary to organize stress fibers in response to TGF $\beta 2$ during the EMT process. Furthermore, the expression of Tpm 1 and Tpm 2 and the formation of stress fibers induced by TGF $\beta 2$ could be inverted by FGF2 addition in MLECs and HLECs [35]. We found that normal MLECs exhibited enhanced migration in response to combined TGF $\beta$ and FGF2 stimulation [35]. Previous studies have examined in detail the major role played by FGF2 in the PCO process $[1,27,72]$. FGF2 and its family members are known to play an important role in the development and maintenance of normal lens differentiation, growth and function [27]. The FGF2 concentration in the eyes may increase after cataract surgery, stimulating cell proliferation and differentiation [72,73]. In a previous study using a rabbit PCO model, the level of active TGF $\beta$ decreased immediately after cataract surgery, then returned to a normal level sufficient to stimulate EMT at about two weeks post-surgery [35]. Similarly, a previous study has shown the dimension of EMT induced by TGF $\beta$ in cooperation with FGFs in cancer cell lines [93]. FGF2 repressed TGF $\beta$-induced EMyoT and enhanced the EMT, conferring greater invasiveness similar to that of activated fibroblasts in cancer cell lines [93]. Moreover, the EMT-induced cells treated with FGF2 and TGF $\beta$ promoted cancer cell invasion [93]. During the EMT process, isoforms of FGF receptors were switched by TGF $\beta$ treatment, causing the cells to be more reactive to FGF2 [93]. Therefore, TGF $\beta$ and FGF2 reciprocally collaborate and may regulate the EMT in the cancer microenvironment [93] and in LECs during PCO development.

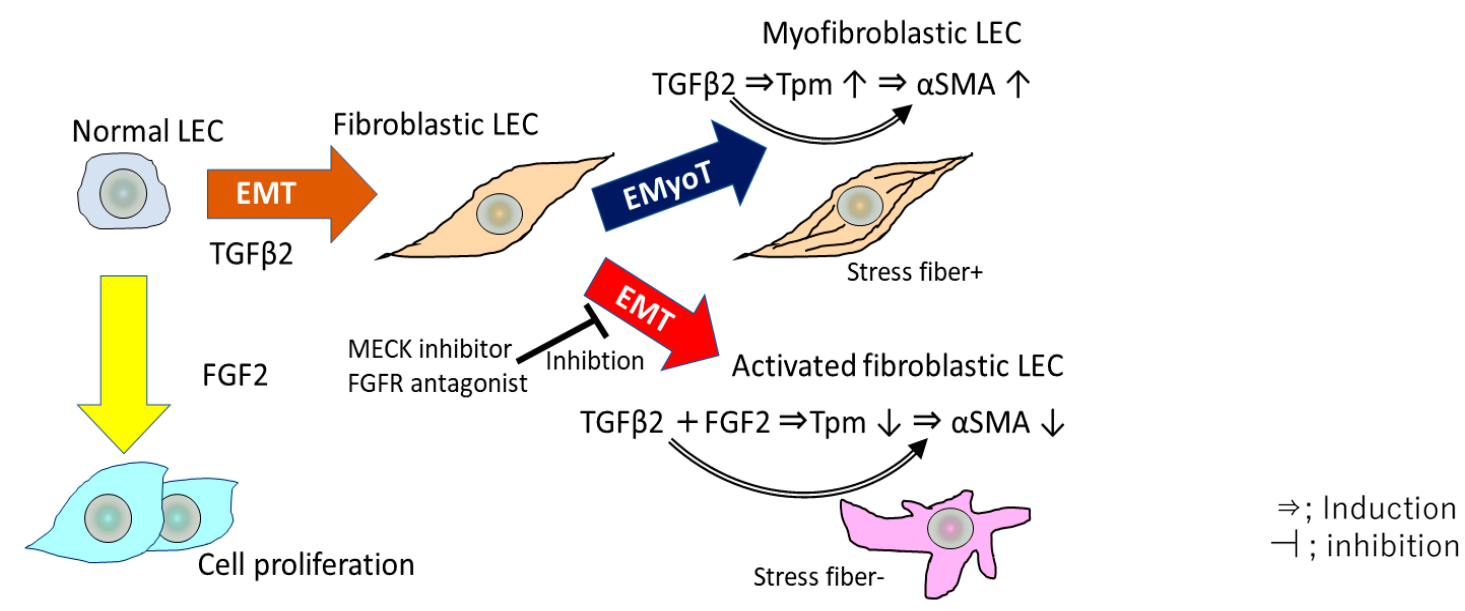

Figure 3. Overview of EMT and EMyoT induction in LECs by TGF $\beta 2$ and FGF2. TGF $\beta$ induces EMyoT and Tpm expression. Tpms promote the formation of stress fibers undergoing EMyoT. FGF2 suppresses the TGF $\beta 2$-induced over-expression of Tpms. Depletion of Tpms by FGF suppresses the formation of stress fibers and activates fibroblastic LECs, which lose cell polarity, inducing cell migration.

Many studies have reported that FGF is a major activator of the mitogen-activated protein kinase/extracellular signal-regulated kinase (MAPK/ERK) 1/2 pathway in the eye lens in vivo [94,95]. 
In our study, FGF2 delivery to TGF $\beta$-treated LECs agitated the EMyoT by reactivating the MAPK/ERK pathway and subsequently enhancing the EMT and cell migration and repressing stress fiber formation [35]. Loss of Tpms induced by FGF2 and TGF- $\beta$ co-treatment was significantly linked to the MAPK/ERK1/2 pathway in MLECs. Conversely, a mitogen-activated protein kinase kinase (MEK) inhibitor (PD98059) and FGFR antagonist (SU5402) abated FGF2-mediated Tpm1/2 and $\alpha$ SMA suppression [35]. These results support our understanding of the mechanism and signaling for the reprogramming of the actin cytoskeleton during EMT, cell proliferation, and invasion of LECs in PCO development and progression. Therefore, we propose that clarifying the physiological link between the levels of FGF2, Tpm1 and Tpm2 expression, and TGF $\beta$-orchestrated EMyoT may help to develop therapeutic targets based on Tpm1 and Tpm2 to prevent PCO (Figure 3).

\section{Tpm 2 Knock-Down Reduced Wound Healing of the Mouse Lens In Vivo}

Upon injury to the anterior capsule, LECs transdifferentiate into fibroblastic cells during the healing process, or so-called EMyoT [96,97], and transform into myofibroblasts positive for $\alpha \mathrm{SMA}$, an established marker of this process. Thus, we used this injury-induced EMT in the lens capsule as a mouse PCO model. To evaluate the physiological role of Tpm2 in PCO, we generated Tpm2 heterozygous knockout mice using clustered regularly interspaced short palindromic repeats/Cas9 (CRISPR/Cas9). Mice with homozygous loss of Tpm2 were embryonically lethal, suggesting that Tpm 2 is necessary for embryonic development and life [89]. Previous studies have also reported that the Tpm1- and 3-knockout mouse models were embryonically lethal [98-100]. Therefore, Tpm2 heterozygous knockout $\left(\mathrm{Tpm}^{+/-}\right)$mice were analyzed as an animal model in which the expression of Tpm 2 was reduced. Tpm $2^{+-}$did not change the expression of Tpm 1 or $\alpha S M A$ in the lens. Therefore, we suggest that the abnormal phenotype observed in $\mathrm{Tpm}^{+/-}$mice is mostly due to Tpm2 gene heterozygous deletion [89]. To induce EMT in the lens as a kind of PCO model, a wound healing model was prepared in seven-week-old mice following a previously reported technique with modifications [97]. In brief, a wound was generated by puncturing the central anterior lens capsule with a 31-gauge needle [89]. Wounded areas at the lens surface showed fibroblast-like tissue changes, indicating EMT [89]. The fibroblastic, EMT/EMyoT-like changes observed in the wounded area were less severe in the $\mathrm{Tpm}^{+/-}$mice than in the wild-type mice, suggesting that the depletion of Tpm2 may suppress wound healing in the mouse lens. These results suggest that $\mathrm{Tpm} 2$ may play a significant role in the initiation and progression of EMT/EMyoT in the lens [89]. Moreover, immunolocalization of $\alpha \mathrm{SMA}$ and Tpm2 is reduced in the wounded area of the lens in Tpm $2^{+/-}$mice. Thus, these results revealed that knock-down of Tpms may suppress the induction of EMT/EMyoT in wound healing and PCO.

\section{Conclusions}

ROS up-regulate TGF $\beta$-mediated signaling, inducing the aberrant expression of certain genes, including those encoding Tpm1, Tpm2, LEDGF, and $\alpha S M A$, which are involved in the induction of EMT in LECs $[17,35,58]$. We identified two types of TGF 32 -induced transdifferentiation of LECs with or without FGF2. One type was transdifferentiated to TGF $\beta$-induced Tpm- and $\alpha$ SMA-positive myofibroblastic cells exhibiting EmyoT-like morphology unaccompanied with FGF2, and the other was transdifferentiated to FGF2-induced Tpm- and $\alpha$ SMA-negative fibroblastic cells observed in EMT accompanied with TGF $\beta 2$ treatment [35]. Elevation in Tpm expression may be related to the progression of EMyoT in mouse and rat PCO and wound healing in MLECs [35,89]. Tpms may act as important biomarkers and therapeutic targets in the treatment of PCO, in the wound healing process and in cancer invasion. Further, we expect that elucidation of the mechanism of Tpm regulation will provide helpful information for the generation of inhibitors of Tpm1 and Tpm2, and ultimately for the treatment and prophylaxis of EMT-related diseases. 
Acknowledgments: This work was supported by a KAKENHI grant from the Japan Society for the Promotion of Science (JSPS) (no. JP23592588 to EK), a grant from the National Eye Institute of the National Institute of Health (NIH) (no. EY024589 to DPS) and a grant for Research for Preventing Blindness (to DPS). Their support is gratefully acknowledged.

Conflicts of Interest: This study was partly funded by Ono Pharmaceutical Co. Ltd. (Osaka, Japan).

\section{Abbreviations}

\begin{tabular}{|c|c|}
\hline LECs & Lens epithelial cells \\
\hline UV & Ultraviolet \\
\hline TGF & Transforming growth factor \\
\hline MLECs & Mouse LECs \\
\hline RLECs & Rat LECs \\
\hline HLECs & Human LECs \\
\hline ECM & Extra cellular matrix protein \\
\hline ROS & Reactive oxygen species \\
\hline$\alpha \mathrm{SMA}$ & $\alpha$-Smooth muscle actin \\
\hline ßig-h3 & TGF- $\beta$-induced protein \\
\hline $\mathrm{PCO}$ & Posterior capsule opacification \\
\hline EMT & Epithelial-mesenchymal transition \\
\hline ASF & Anterior subcapsular fibrosis \\
\hline Tpms & Tropomyosins \\
\hline FGF & Fibroblast growth factor \\
\hline $\operatorname{Prdx}$ & Peroxiredoxin \\
\hline LEDGF & Lens epithelium-cell derived growth factor \\
\hline Hsp & Heat shock protein \\
\hline TIE & TGF $\beta$ inhibitory elements \\
\hline $\operatorname{Prd} x 6^{-/-}$ & Prdx6-deficient \\
\hline DIGE & Difference gel electrophoresis \\
\hline MALDI-TOF & $\begin{array}{l}\text { Matrix-assisted laser desorption/ionization } \\
\text { time-of-flight }\end{array}$ \\
\hline MS & Mass spectrometry \\
\hline ECLE & Extracapsular lens extraction \\
\hline IOL & Intra ocular lens \\
\hline EMyoT & Epithelial-to-myofibroblastic transition \\
\hline MAPK/ERK & $\begin{array}{l}\text { Mitogen-activated protein kinase/extracellular } \\
\text { signal-regulated kinase }\end{array}$ \\
\hline MEK & Mitogen-activated protein kinase kinase \\
\hline CRISPR/Cas9 & $\begin{array}{l}\text { Clustered regularly interspaced short palindromic } \\
\text { repeat/Cas9 }\end{array}$ \\
\hline Tpm $2^{+/-}$ & Tpm2 heterozygous knockout \\
\hline
\end{tabular}

\section{References}

1. McAvoy, J.W. Induction of the eye lens. Differentiation 1980, 17, 137-149. [CrossRef] [PubMed]

2. Thylefors, B. The role of international ophthalmology in blindness prevention. Am. J. Ophthalmol. 1995, 119, 229-230. [CrossRef]

3. Harding, J.J.; Crabbe, J.C. The Lens: Development, Proteins, Metabolism and Cataract, 3rd ed.; Academic Press: New York, NY, USA, 1984; pp. 207-492.

4. Lovicu, F.J.; Schulz, M.W.; Hales, A.M.; Vincent, L.N.; Overbeek, P.A.; Chamberlain, C.G.; McAvoy, J.W. TGFbeta induces morphological and molecular changes similar to human anterior subcapsular cataract. Br. J. Ophthalmol. 2002, 86, 220-226. [CrossRef] [PubMed]

5. McAvoy, J.W.; Chamberlain, C.G.; de Iongh, R.U.; Hales, A.M.; Lovicu, F.J. Peter Bishop Lecture: Growth factors in lens development and cataract: Key roles for fibroblast growth factor and TGF-beta. Clin Experiment. Ophthalmol. 2000, 28, 133-139. [CrossRef] [PubMed] 
6. Jampel, H.D.; Roche, N.; Stark, W.J.; Roberts, A.B. Transforming growth factor-beta in human aqueous humor. Curr. Eye Res. 1990, 9, 963-969. [CrossRef] [PubMed]

7. Granstein, R.D.; Staszewski, R.; Knisely, T.L.; Zeira, E.; Nazareno, R.; Latina, M.; Albert, D.M. Aqueous humor contains transforming growth factor-beta and a small (less than 3500 daltons) inhibitor of thymocyte proliferation. J. Immunol. 1990, 144, 3021-3027. [PubMed]

8. Wilbanks, G.A.; Mammolenti, M.; Streilein, J.W. Studies on the induction of anterior chamber-associated immune deviation (ACAID). III. Induction of ACAID depends upon intraocular transforming growth factor-beta. Eur. J. Immunol. 1992, 22, 165-173. [CrossRef] [PubMed]

9. Tripathi, B.J.; Tripathi, R.C.; Livingston, A.M.; Borisuth, N.S. The role of growth factors in the embryogenesis and differentiation of the eye. Am. J. Anat. 1991, 192, 442-471. [CrossRef] [PubMed]

10. Hales, A.M.; Schulz, M.W.; Chamberlain, C.G.; McAvoy, J.W. TGF-beta 1 induces lens cells to accumulate alpha-smooth muscle actin, a marker for subcapsular cataracts. Curr. Eye Res. 1994, 13, 885-890. [CrossRef] [PubMed]

11. Hales, A.M.; Chamberlain, C.G.; McAvoy, J.W. Cataract induction in lenses cultured with transforming growth factor-beta. Investig. Ophthalmol. Vis. Sci. 1995, 36, 1709-1713.

12. Srinivasan, Y.; Lovicu, F.J.; Overbeek, P.A. Lens-specific expression of transforming growth factor beta1 in transgenic mice causes anterior subcapsular cataracts. J. Clin. Investig. 1998, 101, 625-634. [CrossRef] [PubMed]

13. Wormstone, I.M.; Tamiya, S.; Anderson, I.; Duncan, G. TGF- $\beta 2$-induced matrix modification and cell transdifferentiation in the human lens capsular bag. Investig. Ophthalmol. Vis. Sci. 2002, 43, 2301-2308.

14. Lee, E.H.; Joo, C.K. Role of transforming growth factor-beta in transdifferentiation and fibrosis of lens epithelial cells. Investig. Ophthalmol. Vis. Sci. 1999, 40, 2025-2032.

15. Liu, R.M.; Gaston Pravia, K.A. Oxidative stress and glutathione in TGF-beta-mediated fibrogenesis. Free Radic. Biol. Med. 2010, 48, 1-15. [CrossRef] [PubMed]

16. Fatma, N.; Kubo, E.; Sen, M.; Agarwal, N.; Thoreson, W.B.; Camras, C.B.; Singh, D.P. Peroxiredoxin 6 delivery attenuates TNF-alpha-and glutamate-induced retinal ganglion cell death by limiting ROS levels and maintaining $\mathrm{Ca}^{2+}$ homeostasis. Brain Res. 2008, 1233, 63-78. [CrossRef] [PubMed]

17. Fatma, N.; Kubo, E.; Sharma, P.; Beier, D.R.; Singh, D.P. Impaired homeostasis and phenotypic abnormalities in Prdx6 $6^{-/-}$mice lens epithelial cells by reactive oxygen species: Increased expression and activation of TGFbeta. Cell Death Differ. 2005, 12, 734-750. [CrossRef] [PubMed]

18. Wormstone, I.M. Posterior capsule opacification: A cell biological perspective. Exp. Eye Res. 2002, 74, 337-347. [CrossRef] [PubMed]

19. McDonnell, P.J.; Rowen, S.L.; Glaser, B.M.; Sato, M. Posterior capsule opacification. An in vitro model. Arch. Ophthalmol. 1985, 103, 1378-1381. [CrossRef] [PubMed]

20. Lovicu, F.J.; McAvoy, J.W. Structural analysis of lens epithelial explants induced to differentiate into fibres by fibroblast growth factor (FGF). Exp. Eye Res. 1989, 49, 479-494. [CrossRef]

21. Saika, S. Relationship between posterior capsule opacification and intraocular lens biocompatibility. Prog. Retin. Eye Res. 2004, 23, 283-305. [CrossRef] [PubMed]

22. Marcantonio, J.M.; Syam, P.P.; Liu, C.S.; Duncan, G. Epithelial transdifferentiation and cataract in the human lens. Exp. Eye Res. 2003, 77, 339-346. [CrossRef]

23. Kato, K.; Kurosaka, D.; Nagamoto, T. Apoptotic cell death in rabbit lens after lens extraction. Investig. Ophthalmol. Vis. Sci. 1997, 38, 2322-2330.

24. Kurosaka, D.; Kato, K.; Nagamoto, T. Presence of alpha smooth muscle actin in lens epithelial cells of aphakic rabbit eyes. Br. J. Ophthalmol. 1996, 80, 906-910. [CrossRef] [PubMed]

25. Nagamoto, T.; Eguchi, G. Morphologic compatibility or intraocular lens haptics and the lens capsule. J. Cataract Refract. Surg. 1997, 23, 1254-1259. [CrossRef]

26. Nagamoto, T.; Eguchi, G. Effect of intraocular lens design on migration of lens epithelial cells onto the posterior capsule. J. Cataract Refract. Surg. 1997, 23, 866-872. [CrossRef]

27. Pau, H.; Novotny, G.E. Ultrastructural investigations on anterior capsular cataract. Cellular elements and their relationship to basement membrane and collagen synthesis. Graefes Arch. Clin. Exp. Ophthalmol. 1985, 223, 41-46. [CrossRef] [PubMed] 
28. De Iongh, R.U.; Lovicu, F.J.; Overbeek, P.A.; Schneider, M.D.; Joya, J.; Hardeman, E.D.; McAvoy, J.W. Requirement for TGFbeta receptor signaling during terminal lens fiber differentiation. Development 2001, 128, 3995-4010. [PubMed]

29. De Iongh, R.U.; Wederell, E.; Lovicu, F.J.; McAvoy, J.W. Transforming growth factor-beta-induced epithelial-mesenchymal transition in the lens: a model for cataract formation. Cells Tissues Organs 2005, 179, 43-55. [CrossRef] [PubMed]

30. Lee, E.H.; Seomun, Y.; Hwang, K.H.; Kim, J.E.; Kim, I.S.; Kim, J.H.; Joo, C.K. Overexpression of the transforming growth factor-beta-inducible gene betaig-h3 in anterior polar cataracts. Investig. Ophthalmol. Vis. Sci. 2000, 41, 1840-1845.

31. Medvedovic, M.; Tomlinson, C.R.; Call, M.K.; Grogg, M.; Tsonis, P.A. Gene expression and discovery during lens regeneration in mouse: Regulation of epithelial to mesenchymal transition and lens differentiation. Mol. Vis. 2006, 12, 422-440. [PubMed]

32. Saika, S.; Miyamoto, T.; Ishida, I.; Shirai, K.; Ohnishi, Y.; Ooshima, A.; McAvoy, J.W. TGFbeta-Smad signalling in postoperative human lens epithelial cells. Br. J. Ophthalmol. 2002, 86, 1428-1433. [CrossRef] [PubMed]

33. Seomun, Y.; Kim, J.; Lee, E.H.; Joo, C.K. Overexpression of matrix metalloproteinase-2 mediates phenotypic transformation of lens epithelial cells. Biochem. J. 2001, 358, 41-48. [CrossRef] [PubMed]

34. Border, W.A.; Noble, N.A.; Yamamoto, T.; Harper, J.R.; Yamaguchi, Y.; Pierschbacher, M.D.; Ruoslahti, E. Natural inhibitor of transforming growth factor-beta protects against scarring in experimental kidney disease. Nature 1992, 360, 361-364. [CrossRef] [PubMed]

35. Kubo, E.; Shibata, S.; Shibata, T.; Kiyokawa, E.; Sasaki, H.; Singh, D.P. FGF2 antagonizes aberrant TGFbeta regulation of tropomyosin: role for posterior capsule opacity. J. Cell. Mol. Med. 2017, 21, 916-928. [CrossRef] [PubMed]

36. Kurosaka, D.; Kato, K.; Nagamoto, T.; Negishi, K. Growth factors influence contractility and alpha-smooth muscle actin expression in bovine lens epithelial cells. Investig. Ophthalmol. Vis. Sci. 1995, 36, 1701-1708.

37. Banh, A.; Deschamps, P.A.; Gauldie, J.; Overbeek, P.A.; Sivak, J.G.; West-Mays, J.A. Lens-specific expression of TGF-beta induces anterior subcapsular cataract formation in the absence of Smad3. Investig. Ophthalmol. Vis. Sci. 2006, 47, 3450-3460. [CrossRef] [PubMed]

38. Sasaki, K.; Kojima, M.; Nakaizumi, H.; Kitagawa, K.; Yamada, Y.; Ishizaki, H. Early lens changes seen in patients with atopic dermatitis applying image analysis processing of Scheimpflug and specular microscopic images. Ophthalmologica 1998, 212, 88-94. [CrossRef] [PubMed]

39. Symonds, J.G.; Lovicu, F.J.; Chamberlain, C.G. Posterior capsule opacification-like changes in rat lens explants cultured with TGFbeta and FGF: Effects of cell coverage and regional differences. Exp. Eye Res. 2006, 82, 693-699. [CrossRef] [PubMed]

40. Mansfield, K.J.; Cerra, A.; Chamberlain, C.G. FGF-2 counteracts loss of TGFbeta affected cells from rat lens explants: Implications for PCO (after cataract). Mol. Vis. 2004, 10, 521-532. [PubMed]

41. Schulz, M.W.; Chamberlain, C.G.; McAvoy, J.W. Binding of FGF-1 and FGF-2 to heparan sulphate proteoglycans of the mammalian lens capsule. Growth Factors 1997, 14, 1-13. [CrossRef] [PubMed]

42. Lovicu, F.J.; McAvoy, J.W. Growth factor regulation of lens development. Dev. Biol. 2005, 280, 1-14. [CrossRef] [PubMed]

43. Chamberlain, C.G.; McAvoy, J.W. Evidence that fibroblast growth factor promotes lens fibre differentiation. Curr. Eye Res. 1987, 6, 1165-1169. [CrossRef] [PubMed]

44. McAvoy, J.W.; Chamberlain, C.G. Fibroblast growth factor (FGF) induces different responses in lens epithelial cells depending on its concentration. Development 1989, 107, 221-228. [PubMed]

45. Chamberlain, C.G.; McAvoy, J.W. Induction of lens fibre differentiation by acidic and basic fibroblast growth factor (FGF). Growth Factors 1989, 1, 125-134. [CrossRef] [PubMed]

46. Wang, Q.Q.; Liu, F.; Chen, X.S.; Ma, X.J.; Zeng, H.Q.; Yang, Z.M. Transcriptome profiling of early developing cotton fiber by deep-sequencing reveals significantly differential expression of genes in a fuzzless/lintless mutant. Genomics 2010, 96, 369-376. [CrossRef] [PubMed]

47. Lovicu, F.J.; Overbeek, P.A. Overlapping effects of different members of the FGF family on lens fiber differentiation in transgenic mice. Development 1998, 125, 3365-3377. [PubMed]

48. Robinson, M.L.; MacMillan-Crow, L.A.; Thompson, J.A.; Overbeek, P.A. Expression of a truncated FGF receptor results in defective lens development in transgenic mice. Development 1995, 121, 3959-3967. [PubMed] 
49. Robinson, M.L.; Overbeek, P.A.; Verran, D.J.; Grizzle, W.E.; Stockard, C.R.; Friesel, R.; Maciag, T.; Thompson, J.A. Extracellular FGF-1 acts as a lens differentiation factor in transgenic mice. Development 1995, 121, 505-514. [PubMed]

50. Wang, Q.; McAvoy, J.W.; Lovicu, F.J. Growth factor signaling in vitreous humor-induced lens fiber differentiation. Investig. Ophthalmol. Vis. Sci. 2010, 51, 3599-3610. [CrossRef] [PubMed]

51. Hayashi, N.; Kato, H.; Kiyosawa, T.; Hayashi, H.; Oshima, K.; Yamaoka, M. The change in immunohistochemical localization of basic fibroblast growth factor (b-FGF) around the lens capsule after extracapsular extraction. Nihon Ganka Gakkai Zasshi 1991, 95, 621-624. [PubMed]

52. Lovicu, F.J.; McAvoy, J.W. Localization of acidic fibroblast growth factor, basic fibroblast growth factor, and heparan sulphate proteoglycan in rat lens: implications for lens polarity and growth patterns. Investig. Ophthalmol. Vis. Sci. 1993, 34, 3355-3365.

53. Nishi, O.; Nishi, K.; Fujiwara, T.; Shirasawa, E.; Ohmoto, Y. Effects of the cytokines on the proliferation of and collagen synthesis by human cataract lens epithelial cells. Br. J. Ophthalmol. 1996, 80, 63-68. [CrossRef] [PubMed]

54. Gleizes, P.E.; Munger, J.S.; Nunes, I.; Harpel, J.G.; Mazzieri, R.; Noguera, I.; Rifkin, D.B. TGF-beta latency: Biological significance and mechanisms of activation. Stem Cells 1997, 15, 190-197. [CrossRef] [PubMed]

55. Koli, K.; Saharinen, J.; Hyytiainen, M.; Penttinen, C.; Keski-Oja, J. Latency, activation, and binding proteins of TGF-beta. Microsc. Res. Technol. 2001, 52, 354-362. [CrossRef]

56. Annes, J.P.; Munger, J.S.; Rifkin, D.B. Making sense of latent TGFbeta activation. J. Cell. Sci. 2003, 116, 217-224. [CrossRef] [PubMed]

57. Herrera, B.; Murillo, M.M.; Alvarez-Barrientos, A.; Beltran, J.; Fernandez, M.; Fabregat, I. Source of early reactive oxygen species in the apoptosis induced by transforming growth factor-beta in fetal rat hepatocytes. Free Radic. Biol. Med. 2004, 36, 16-26. [CrossRef] [PubMed]

58. Sharma, P.; Fatma, N.; Kubo, E.; Shinohara, T.; Chylack, L.T., Jr.; Singh, D.P. Lens epithelium-derived growth factor relieves transforming growth factor-beta1-induced transcription repression of heat shock proteins in human lens epithelial cells. J. Biol. Chem. 2003, 278, 20037-20046. [CrossRef] [PubMed]

59. Nakamura, M.; Singh, D.P.; Kubo, E.; Chylack, L.T., Jr.; Shinohara, T. LEDGF: Survival of embryonic chick retinal photoreceptor cells. Investig. Ophthalmol. Vis. Sci. 2000, 41, 1168-1175.

60. Sharma, P.; Singh, D.P.; Fatma, N.; Chylack, L.T., Jr.; Shinohara, T. Activation of LEDGF gene by thermal-and oxidative-stresses. Biochem. Biophys. Res. Commun. 2000, 276, 1320-1324. [CrossRef] [PubMed]

61. Singh, D.P.; Kimura, A.; Chylack, L.T., Jr.; Shinohara, T. Lens epithelium-derived growth factor (LEDGF/p75) and p52 are derived from a single gene by alternative splicing. Gene 2000, 242, 265-273. [CrossRef]

62. Singh, D.P.; Ohguro, N.; Kikuchi, T.; Sueno, T.; Reddy, V.N.; Yuge, K.; Chylack, L.T., Jr.; Shinohara, T. Lens epithelium-derived growth factor: Effects on growth and survival of lens epithelial cells, keratinocytes, and fibroblasts. Biochem. Biophys. Res. Commun. 2000, 267, 373-381. [CrossRef] [PubMed]

63. Fatma, N.; Singh, D.P.; Shinohara, T.; Chylack, L.T. Transcriptional regulation of the antioxidant protein 2 gene, a thiol-specific antioxidant, by lens epithelium-derived growth factor to protect cells from oxidative stress. J. Biol. Chem. 2001, 276, 48899-48907. [CrossRef] [PubMed]

64. Kerr, L.D.; Miller, D.B.; Matrisian, L.M. TGF-beta 1 inhibition of transin/stromelysin gene expression is mediated through a Fos binding sequence. Cell 1990, 61, 267-278. [CrossRef]

65. White, L.A.; Mitchell, T.I.; Brinckerhoff, C.E. Transforming growth factor beta inhibitory element in the rabbit matrix metalloproteinase-1 (collagenase-1) gene functions as a repressor of constitutive transcription. Biochim. Biophys. Acta 2000, 1490, 259-268. [CrossRef]

66. Singh, D.P.; Fatma, N.; Kimura, A.; Chylack, L.T., Jr.; Shinohara, T. LEDGF binds to heat shock and stress-related element to activate the expression of stress-related genes. Biochem. Biophys. Res. Commun. 2001, 283, 943-955. [CrossRef] [PubMed]

67. Kubo, E.; Fatma, N.; Sharma, P.; Shinohara, T.; Chylack, L.T., Jr.; Singh, D.P. Transactivation of involucrin, a marker of differentiation in keratinocyte, by lens epithelium derived growth factor (LEDGF). J. Mol. Biol. 2002, 320, 1053-1063. [CrossRef]

68. Chae, H.Z.; Robison, K.; Poole, L.B.; Church, G.; Storz, G.; Rhee, S.G. Cloning and sequencing of thiol-specific antioxidant from mammalian brain: Alkyl hydroperoxide reductase and thiol-specific antioxidant define a large family of antioxidant enzymes. Proc. Natl. Acad. Sci. USA 1994, 91, 7017-7021. [CrossRef] [PubMed] 
69. Kubo, E.; Miyazawa, T.; Fatma, N.; Akagi, Y.; Singh, D.P. Development- and age-associated expression pattern of peroxiredoxin 6, and its regulation in murine ocular lens. Mech. Ageing Dev. 2006, 127, $249-256$. [CrossRef] [PubMed]

70. Chae, H.Z.; Uhm, T.B.; Rhee, S.G. Dimerization of thiol-specific antioxidant and the essential role of cysteine 47. Proc. Natl. Acad. Sci. USA 1994, 91, 7022-7026. [CrossRef] [PubMed]

71. Kubo, E.; Singh, D.P.; Fatma, N.; Akagi, Y. TAT-mediated peroxiredoxin 5 and 6 protein transduction protects against high-glucose-induced cytotoxicity in retinal pericytes. Life Sci. 2009, 84, 857-864. [CrossRef] [PubMed]

72. Kubo, E.; Hasanova, N.; Tanaka, Y.; Fatma, N.; Takamura, Y.; Singh, D.P.; Akagi, Y. Protein Expression Profiling of Lens Epithelial Cells from Prdx6-depleted Mice and Their Vulnerability to UV Radiation Exposure. Am. J. Physiol. Cell. Physiol. 2010, 298, 342-354. [CrossRef] [PubMed]

73. Kubo, E.; Fatma, N.; Akagi, Y.; Beier, D.R.; Singh, S.P.; Singh, D.P. TAT-mediated PRDX6 protein transduction protects against eye lens epithelial cell death and delays lens opacity. Am. J. Physiol. Cell. Physiol. 2008, 294, C842-C855. [CrossRef] [PubMed]

74. Kurosaka, D.; Nagamoto, T. Inhibitory effect of TGF-beta 2 in human aqueous humor on bovine lens epithelial cell proliferation. Investig. Ophthalmol. Vis. Sci. 1994, 35, 3408-3412.

75. Cousins, S.W.; McCabe, M.M.; Danielpour, D.; Streilein, J.W. Identification of transforming growth factor-beta as an immunosuppressive factor in aqueous humor. Investig. Ophthalmol. Vis. Sci. 1991, 32, 2201-2211.

76. Chong, H.; Vodovotz, Y.; Cox, G.W.; Barcellos-Hoff, M.H. Immunocytochemical localization of latent transforming growth factor-beta1 activation by stimulated macrophages. J. Cell. Physiol. 1999, 178, 275-283. [CrossRef]

77. Barcelo, S.; Gardiner, J.M.; Gescher, A.; Chipman, J.K. CYP2E1-mediated mechanism of anti-genotoxicity of the broccoli constituent sulforaphane. Carcinogenesis 1996, 17, 277-282. [CrossRef] [PubMed]

78. Hildeman, D.A.; Mitchell, T.; Teague, T.K.; Henson, P.; Day, B.J.; Kappler, J.; Marrack, P.C. Reactive oxygen species regulate activation-induced T cell apoptosis. Immunity 1999, 10, 735-744. [CrossRef]

79. Avery, R.L.; Glaser, B.M. Inhibition of retinal pigment epithelial cell attachment by a synthetic peptide derived from the cell-binding domain of fibronectin. Arch. Ophthalmol. 1986, 104, 1220-1222. [CrossRef] [PubMed]

80. Kubo, E.; Hasanova, N.; Fatma, N.; Sasaki, H.; Singh, D.P. Elevated tropomyosin expression is associated with epithelial-mesenchymal transition of lens epithelial cells. J. Cell. Mol. Med. 2013, 17, 212-221. [CrossRef] [PubMed]

81. Edlund, S.; Landstrom, M.; Heldin, C.H.; Aspenstrom, P. Transforming growth factor-beta-induced mobilization of actin cytoskeleton requires signaling by small GTPases Cdc42 and RhoA. Mol. Biol. Cell. 2002, 13, 902-914. [CrossRef] [PubMed]

82. Wawro, B.; Greenfield, N.J.; Wear, M.A.; Cooper, J.A.; Higgs, H.N.; Hitchcock-DeGregori, S.E. Tropomyosin regulates elongation by formin at the fast-growing end of the actin filament. Biochemistry 2007, 46, 8146-8155. [CrossRef] [PubMed]

83. Geeves, M.A.; Hitchcock-DeGregori, S.E.; Gunning, P.W. A systematic nomenclature for mammalian tropomyosin isoforms. J. Muscle Res. Cell Motil. 2015, 36, 147-153. [CrossRef] [PubMed]

84. Schevzov, G.; Whittaker, S.P.; Fath, T.; Lin, J.J.; Gunning, P.W. Tropomyosin isoforms and reagents. Bioarchitecture 2011, 1, 135-164. [CrossRef] [PubMed]

85. Varga, A.E.; Stourman, N.V.; Zheng, Q.; Safina, A.F.; Quan, L.; Li, X.; Sossey-Alaoui, K.; Bakin, A.V. Silencing of the Tropomyosin-1 gene by DNA methylation alters tumor suppressor function of TGF-beta. Oncogene 2005, 24, 5043-5052. [CrossRef] [PubMed]

86. Bakin, A.V.; Safina, A.; Rinehart, C.; Daroqui, C.; Darbary, H.; Helfman, D.M. A critical role of tropomyosins in TGF-beta regulation of the actin cytoskeleton and cell motility in epithelial cells. Mol. Biol. Cell. 2004, 15, 4682-4694. [CrossRef] [PubMed]

87. Lee, A.; Fischer, R.S.; Fowler, V.M. Stabilization and remodeling of the membrane skeleton during lens fiber cell differentiation and maturation. Dev. Dyn 2000, 217, 257-270. [CrossRef]

88. Zheng, Q.; Safina, A.; Bakin, A.V. Role of high-molecular weight tropomyosins in TGF-beta-mediated control of cell motility. Int. J. Cancer 2008, 122, 78-90. [CrossRef] [PubMed] 
89. Shibata, T.; Shibata, S.; Ishigaki, Y.; Kiyokawa, E.; Ikawa, M.; Singh, D.P.; Sasaki, H.; Kubo, E. Tropomyosin 2 heterozygous knockout in mice using CRISPR-Cas9 system displays the inhibition of injury-induced epithelial-mesenchymal transition, and lens opacity. Mech. Ageing Dev. 2018, 171, 24-30. [CrossRef] [PubMed]

90. Pawlak, G.; Helfman, D.M. Cytoskeletal changes in cell transformation and tumorigenesis. Curr. Opin. Genet. Dev. 2001, 11, 41-47. [CrossRef]

91. Cobo, L.M.; Ohsawa, E.; Chandler, D.; Arguello, R.; George, G. Pathogenesis of capsular opacification after extracapsular cataract extraction. An animal model. Ophthalmology 1984, 91, 857-863. [CrossRef]

92. Rungger-Brandle, E.; Conti, A.; Leuenberger, P.M.; Rungger, D. Expression of alphasmooth muscle actin in lens epithelia from human donors and cataract patients. Exp. Eye Res. 2005, 81, 539-550. [CrossRef] [PubMed]

93. Shirakihara, T.; Horiguchi, K.; Miyazawa, K.; Ehata, S.; Shibata, T.; Morita, I.; Miyazono, K.; Saitoh, M. TGF-beta regulates isoform switching of FGF receptors and epithelial-mesenchymal transition. EMBO J. 2011, 30, 783-795. [CrossRef] [PubMed]

94. Govindarajan, V.; Overbeek, P.A. Secreted FGFR3, but not FGFR1, inhibits lens fiber differentiation. Development 2001, 128, 1617-1627. [PubMed]

95. Zhao, H.; Yang, T.; Madakashira, B.P.; Thiels, C.A.; Bechtle, C.A.; Garcia, C.M.; Zhang, H.; Yu, K.; Ornitz, D.M.; Beebe, D.C.; Robinson, M.L. Fibroblast growth factor receptor signaling is essential for lens fiber cell differentiation. Dev. Biol. 2008, 318, 276-288. [CrossRef] [PubMed]

96. Hay, E.D. An overview of epithelio-mesenchymal transformation. Acta Anat. 1995, 154, 8-20. [CrossRef] [PubMed]

97. Tanaka, S.; Sumioka, T.; Fujita, N.; Kitano, A.; Okada, Y.; Yamanaka, O.; Flanders, K.C.; Miyajima, M.; Saika, S. Suppression of injury-induced epithelial-mesenchymal transition in a mouse lens epithelium lacking tenascin-C. Mol. Vis. 2010, 16, 1194-1205. [PubMed]

98. Jagatheesan, G.; Rajan, S.; Wieczorek, D.F. Investigations into tropomyosin function using mouse models. J. Mol. Cell. Cardiol. 2010, 48, 893-898. [CrossRef] [PubMed]

99. Blanchard, E.M.; Iizuka, K.; Christe, M.; Conner, D.A.; Geisterfer-Lowrance, A.; Schoen, F.J.; Maughan, D.W.; Seidman, C.E.; Seidman, J.G. Targeted ablation of the murine alpha-tropomyosin gene. Circ. Res. 1997, 81, 1005-1010. [CrossRef] [PubMed]

100. Hook, J.; Lemckert, F.; Qin, H.; Schevzov, G.; Gunning, P. Gamma tropomyosin gene products are required for embryonic development. Mol. Cell. Biol 2004, 24, 2318-2323. [CrossRef] [PubMed] 